\title{
Molecular Characterization of Bacteriocinogenic, Antifungal and Probiotic Lactic Acid Bacteria Isolated from Chicken Gastrointestinal Tract
}

\author{
Venkatasatyanarayana Nallala, K. Jeevaratnam* \\ Department of Biochemistry and Molecular Biology, School of Life Sciences, Pondicherry University, \\ Pondicherry, India \\ Email: *jeevskj@gmail.com
}

Received 20 July 2015; accepted 24 August 2015; published 27 August 2015

Copyright (C) 2015 by authors and Scientific Research Publishing Inc. This work is licensed under the Creative Commons Attribution International License (CC BY). http://creativecommons.org/licenses/by/4.0/

(c) (i) Open Access

\section{Abstract}

In this study, bacteriocinogenic Lactobacillus plantarum isolates capable of inhibiting food- and feed-borne filamentous fungi from the gastrointestinal tract (GIT) of broiler chicken were identified using $16 \mathrm{~S}$ rRNA gene sequencing and further evaluated for probiotic properties in vitro. Six potent lactobacilli were selected from one hundred and thirteen isolates for the present study based on their ability to inhibit both pathogenic bacteria and filamentous fungi. They were characterized using various physiological, biochemical and molecular methods. They were acetoin producers, homo fermentative, catalase-negative and producing racemic lactic acid (10 - $20 \mathrm{mM}$ ). All the six isolates exhibited varied sugar utilization and RAPD pattern, indicated their strain level genotypic variation. The $16 \mathrm{~S}$ rRNA gene sequence and multiplex PCR analysis confirmed that these isolates were Lactobacillus plantarum. The isolates being resistant to low $\mathrm{pH}(2.0)$ and bile salt $(0.6 \%)$ could survive in the gastrointestinal tract of host indicating their potential probiotic application. The isolates were non-pathogenic ( $\gamma$-hemolytic) and exhibited resistance to antibiotics ciprofloxacin, nalidixic acid, norfloxacin, nitrofurantoin, colistin and streptomycin. They demonstrated strong autoaggregating phenotype ranging from $78 \%$ to $86 \%$ and showed $49 \%-61 \%$ and $30 \%$ - 46\% coaggregation with $E$. coli MTCC 728 and $L$. monocytogenes MTCC 657, respectively. The percentage of hydrophobicity ranged from $16 \%-33 \%$ for all the isolates showing that surface was rather hydrophilic. They exhibited $\beta$-galactosidase activity ranging from 1036 - $1179 \mathrm{MU}$, bile salt hydrolase activity assisting to reduce serum cholesterol and produced the anti-Listerial bacteri-

\footnotetext{
"Corresponding author.
}

How to cite this paper: Nallala, V. and Jeevaratnam, K. (2015) Molecular Characterization of Bacteriocinogenic, Antifungal and Probiotic Lactic Acid Bacteria Isolated from Chicken Gastrointestinal Tract. Advances in Microbiology, 5, 644-660. 
ocin. The strong inhibitory activity of these isolates against food spoilage molds and bacteria with probiotic properties indicates their potential application as food preservatives.

\title{
Keywords
}

\author{
Broiler Chicken, Filamentous Fungi, Lactobacillus plantarum, Probiotic
}

\section{Introduction}

Molds are frequent and important spoilage organisms in the food and feed systems, causing huge economic losses to industrials and health hazards to consumers [1]. The major species involved in the food spoilage are Aspergillus, Fusarium, Penicillium and Mucor. Chemical preservatives such as propionic, sorbic and acetic acids and their salts only decrease fungal infections and fall short of contaminant elimination. Additionally, some molds have acquired the ability to degrade chemical preservatives such as sorbate [2]. The raising consumer concerns over the usage of chemical preservatives in food processing [3] and their focus on minimally processed green-labeled foods is driving the food industry towards lactic acid bacterium based food preservation.

Biopreservation is the use of lactic acid bacteria (LAB) and/or their antimicrobial compounds to prevent spoilage and to extend the shelf life of foods. LAB has a long history of use as a bio-preservative and is "generally regarded as safe" (GRAS). LAB is Gram-positive, anaerobic but aero-tolerant, non-spore forming, non-motile, rod and coccus-shaped organisms. The preserving ability of LAB is mainly related to the production of organic acids and reduction of $\mathrm{pH}$, which generally restricts growth of pathogenic bacteria and fungi [4]. However, there are other metabolic products such as cyclic dipeptides and bacteriocins/antimicrobial peptides reported to involve in the preservation of many processed and natural foods [5]. There are many reports on antifungal activities and possible application as biopreservatives of LAB from various sources [6] [7].

The GIT of chicken harbors a huge collection of micro flora more than 650 species, of which more than half are previously unknown bacterial genera [8]. Lactobacilli from chicken origin are a good source of antimicrobial peptides [9]. A very limited data are available in the literature on antibacterial and antifungal probiotic lactobacilli isolated from chicken GIT, which is known for harbouring highly diversified microbial species [10]. Probiotics are defined as live microorganisms that when administered in adequate amounts, they confer a health benefit on the host [11]. The principle requisite for selection of good probiotic includes product safety for human and animal consumption and survival in the GIT.

In the present study, we have isolated and characterized LAB from chicken GIT with strong and broad antibacterial and antifungal activity against pathogenic food spoilage microbes. The probiotic characteristics were also tested in vitro.

\section{Materials and Methods}

\subsection{Isolates, Cultures and Growth Conditions}

LAB was isolated from the crop, intestine, gizzard and ceca of seven weeks old broiler chicken. Serially diluted samples were inoculated onto acidified de Mann-Rogosa-Sharpe (MRS) agar (Himedia, India) and incubated anaerobically at $37^{\circ} \mathrm{C}$ for $48 \mathrm{~h}$. The MRS agar plates were acidified at $\mathrm{pH} 4.0$ and supplemented with $0.2 \%$ (W/V) sodium azide to support the growth of LAB during isolation. After cultivation, creamy, opaque and elevated single colonies were picked and streaked on MRS agar. Gram positive, catalase negative isolates were selected and stored at $-70^{\circ} \mathrm{C}$ in MRS broth with $30 \%$ glycerol.

The molds Aspergillus niger MTCC 4325, Eurotium species MTCC 4647, Penicillium expansum MTCC 8241, Penicillium roqueforti MTCC 933, bacterial pathogens Listeria monocytogenes MTCC 657, Staphylococcus aureus MTCC 737, Escherichia coli MTCC 728, Aeromonas hydrophila MTCC 1739, Pseudomonas aeruginosa MTCC 2295 and LAB Lactobacillus plantarum MTCC 6161, Lactobacillus lactis MTCC 3038, Lactobacillus fermentum MTCC 1745, Leuconostoc mesenteroides MTCC 107, Lactococcus lactis subsp. Chacetylactis MTCC 3042, Lactobacillus rhamnosus MTCC 1408 were procured from the Microbial Type Culture Collection (MTCC), Institute of Microbial Technology, Chandigarh, India. The target fungi were selected as representative of baked goods spoilage fungi and bacterial pathogens were selected representing frequent food contaminants. 
Molds were cultivated on potato dextrose agar (PDA) (Himedia, India) slants at $30^{\circ} \mathrm{C}$ for 6 days or till sporulation and stored at $4^{\circ} \mathrm{C}$. The spores were harvested from slants in sterile peptone water $(0.2 \% \mathrm{~W} / \mathrm{V})$ to prepare the inoculum containing $1 \times 10^{5}$ spores per $\mathrm{mL}$. Bacterial pathogens were cultured in tryptone-glucose-yeast extract (TGY) (Himedia, India) broth at $37^{\circ} \mathrm{C}$ for $24 \mathrm{~h}$ and stored at $-70^{\circ} \mathrm{C}$ in TGY broth with $30 \%$ glycerol. E. coli $\mathrm{DH} 5 \alpha$ was grown in Luria-Bertani (LB) medium at $37^{\circ} \mathrm{C}$ and $180 \mathrm{rpm}$. E. coli transformants were cultivated in LB medium supplemented with ampicillin (50 $\mathrm{gg} / \mathrm{ml}$ ) (Hi media, India). Plasmid pTZ57R/T (Thermo Scientific, USA) was used for the construction of recombinant plasmid carrying the plantaricin EF gene.

\subsection{Primary Screening of Isolates for Antifungal Activity}

Bacterial isolates grown in $5 \mathrm{~mL}$ of MRS broth at $37^{\circ} \mathrm{C}$ for $24 \mathrm{~h}$ were checked for their antifungal activity against target fungi by the overlay method described by Y.I. Hassan and L.B. Bullerman, 2008 [12] with minor modifications. A total of $10 \mu \mathrm{L}$ of each LAB isolate were added as a discrete spots in the centre of buffered MRS agar plates and incubated anaerobically at $37^{\circ} \mathrm{C}$ for $24 \mathrm{~h}$. The medium was buffered at $\mathrm{pH} 6.5$ by 75 $\mathrm{m} \cdot \mathrm{mol} \cdot \mathrm{L}^{-1} \mathrm{KH}_{2} \mathrm{PO}_{4}$ to avoid the effect of $\mathrm{pH}$ on antifungal activity. After incubation, the plates were overlaid with $15 \mathrm{~mL}$ soft PDA $\left(0.8 \%\right.$ agar) containing $1 \times 10^{5}$ spores per $\mathrm{mL}$ and incubated at $30^{\circ} \mathrm{C}$. The incubation period lasted up to 4 days and clear zones of inhibition around the bacterial spot were recorded and scored as follows: $(-)$ no visible inhibition; $(+)$ spore formation delayed with a small clear zone around the colony; $(++)$ spore formation delayed with a good clear zone around the colony; $(+++)$ extensive suppression of spore formation and mycelial growth with definite clear zone around the colony. The experiment was performed in triplicates and Lactobacillus isolates with very good antagonistic activity were selected for further studies.

Antifungal activity of LAB isolates on the growth of Aspergillus niger was investigated by dual agar plate assay or confrontation assay described by Y.I. Hassan and L.B. Bullerman, 2008 [12] with minor modification of using buffered MRS agar. MRS agar buffered at $\mathrm{pH} 6.5$ was mixed with $100 \mu \mathrm{L}$ of actively grown LAB culture at the bottom of a petri plate and incubated at $37^{\circ} \mathrm{C}$ for $24 \mathrm{~h}$. After incubation, the plates were overlaid with soft PDA and $10 \mu \mathrm{L}$ of mold spore suspension was inoculated as a discrete spot on to the centre of each plate. Then the plates were incubated at $30^{\circ} \mathrm{C}$ for 10 days. The diameters of the growing mold colonies were measured in control and test plates. These data were used to plot growth curves and to select potent antifungal LAB isolate. The nature of antifungal activity was investigated with 10 -fold-concentrated culture filtrate treated with acid protease $\left(2 \mathrm{mg} \cdot \mathrm{ml}^{-1}\right.$ ) (Sigma, India) in $10 \mathrm{mM}$ citrate buffer $\mathrm{pH} 3.0$ and incubated at $37^{\circ} \mathrm{C}$ for $3 \mathrm{~h}$ (Magnusson and Schnürer, 2001). Before evaluating the antifungal activity, the $\mathrm{pH}$ of the supernatant was readjusted to $\mathrm{pH}$ value 5.0. Both 10-fold-concentrated MRS broth treated with enzyme and $\mathrm{pH}$ adjusted 10 -fold-concentrated samples served as controls.

\subsection{Screening of Isolates for Antibacterial Activity}

Antibacterial activities of LAB isolates were determined against target bacterial pathogens by agar well diffusion method as described earlier [13]. The bacteriocinogenic nature of antibacterial activity was determined by using 10 -fold-concentrated CFS treated with acid protease $\left(2 \mathrm{mg} \cdot \mathrm{ml}^{-1}\right.$ ) (Sigma, India) in $10 \mathrm{mM}$ citrate buffer $\mathrm{pH} 3.0$ and incubated at $37^{\circ} \mathrm{C}$ for $3 \mathrm{~h}$. Antibacterial activity was checked at $\mathrm{pH} 6.0$ against Staphylococcus aureus and compared with control which was also processed in a similar way without enzyme [14].

\subsection{Identification of Isolates}

\subsubsection{Classical Characterization of Potent Antifungal and Antibacterial Isolates}

Physiological and biochemical attributes of potent antifungal and antibacterial LAB isolates were determined by methods as described earlier [15]. Sugar utilization profile of isolates was resolved by using the HiCarbo Kit (Himedia, India). The configurations of lactic acid enantiomers and their concentrations were determined by enzymatic method as described earlier [16] [17].

$$
\text { Lactate }(\mathrm{mM})=\frac{\Delta A_{340} \times 3}{6.22 \times \text { vol of sample } \times 1}
$$

where 3 is reaction volume, 6.22 is mM extinction coefficient of NADH at $340 \mathrm{~nm}$ and 1 is path length of cuvette in $\mathrm{cm}$. 


\subsubsection{Antibiotic Susceptibility}

Antibiotic susceptibility of isolates was assayed by the disc diffusion method. To determine antibiotic susceptibility, isolate was seeded in MRS agar ( $1 \%$ agar w/v) with $10^{8} \mathrm{CFU} / \mathrm{mL}$ and allowed to get solidified. The commercial antibiotic discs of different concentrations were placed on the surface of the medium and incubated at $37^{\circ} \mathrm{C}$ for $24 \mathrm{~h}$. The resistance and sensitivity were noted as per CLSI/NCCLS standard [18].

\subsubsection{Molecular Characterization of Isolates}

Genomic DNA was extracted using the method of Anderson and Mckay [19]. RAPD finger printing was performed using the primers M13 (5'-GAGGGTGGCGGTTCT-3') and R2 (5'-GGCGACCACTAG-3') as described earlier [13]. The polymorphic DNA pattern was analyzed by running amplified products in $1.5 \%$ agarose gel electrophoresis with 500 bp DNA ladder (Sigma, USA). M13 RAPD profiles were visualized under UV light and analyzed with Quantity one software (Bio-Rad, USA). The similarities were calculated using the Dice coefficient. The dendrogram was constructed by means of the unweighted pair group method using arithmetic averages (UPGMA).

The potent isolates were identified by $16 \mathrm{~S}$ ribosomal RNA (rRNA) sequencing after amplification using primers fKJ (5'-CATTGGGACTGAGACACTGC-3') and rKJ (5'-CACCGCGACATGCTGATTC-3') [17]. The sequences were compared with reference sequences in Gen Bank at the National Centre for Biotechnology Information (NCBI) using a BLASTn program. Phylogenetic tree for isolates was constructed using the neighbor-joining method with MEGA 5.0 software. The 16S rRNA sequences of isolates were deposited in Gen Bank.

\subsubsection{Multiplex PCR}

Multiplex PCR assay was performed to differentiate Lactobacillus plantarum, Lactobacillus pentosus and Lactobacillus paraplantarum with primers paraF (5'-GTCACAGGCATTACGAAAAC-3'), pentF (5'-CAGTGGC GCGGTTGATATC-3'), planF (5'-CCGTTTATGCGGAACACCTA-3') and PREV (5'-TCGGGATTACCAAA CATCAC-3') [20].

\subsection{PCR Amplification and Cloning of Plantaricin EF Gene}

PCR amplification of plantaricin gene EF (plnEF) was performed from genomic DNA of isolates using primers plnEF-F (5'-GGTGGTTTTAATCGGGGCGG-3') and plnEF-R (5'-ACTTGATGGCTTGAACTATCC-3') [21]. $50 \mu \mathrm{L}$ of PCR mixture contained $0.5 \mu \mathrm{M}$ of primer, $100 \mathrm{ng}$ of genomic DNA, $1 \mathrm{X}$ Taq DNA polymerase buffer, $1 \mathrm{U}$ of Taq DNA polymerase, $0.2 \mathrm{mM}$ of each dNTP and $1.5 \mathrm{mM} \mathrm{MgCl}_{2}$. PlnEF gene amplification was performed in a thermo cycler at $94^{\circ} \mathrm{C}$ for $3 \mathrm{~min}$, followed by 29 cycles of $1 \mathrm{~min}$ at $94^{\circ} \mathrm{C}, 1 \mathrm{~min}$ at $58^{\circ} \mathrm{C}$ and $2 \mathrm{~min}$ at $72^{\circ} \mathrm{C}$ with an extension of $72^{\circ} \mathrm{C}$ for 7 min. Amplified plantaricin EF gene was purified using a clean-up kit (Merck Bioscience, India) and ligated into pTZ57R/T cloning vector by TA cloning method. Ligation mixture was transformed into E. coli DH5 $\alpha$ competent cells, using standard procedure described by Sambrook et al., 2001 [22]. The recombinant plasmid was confirmed by restriction digestion by EcoR I and Hind III, as well as by sequencing. Sequencing was performed at Eurofins Genomics India Pvt Ltd, India and sequence was submitted to Gen Bank data base.

\subsection{Probiotic Properties of Isolates}

\subsubsection{Auto-Aggregation, Co-Aggregation and Cell Surface Hydrophobicity}

Aggregation between the cells of same strains (auto-aggregation) or between genetically different strains (coaggregation) is of considerable importance in the human gut where probiotics are to be active and such abilities favour bacterial maintenance in the gastrointestinal tract. The autoaggregation and coaggregation (with E. coli, Listeria monocytogenes) assays were performed according to Osmanagaoglu et al., 2010 [23]. Isolates were grown in MRS broth for $18 \mathrm{~h}$ at $37^{\circ} \mathrm{C}$. Cells were harvested and washed twice with phosphate buffer saline (PBS) $\mathrm{pH}$ 7.0. The cells were suspended in PBS, pH 7.0 and adjusted to an optical density at $\mathrm{A}_{600}$ to1.0. To three milliliters of cell suspension, equal volumes of n-hexadecane was added, vortexed for $2 \mathrm{~min}$ and allowed to stand for $30 \mathrm{~min}$ for phase separation. The aqueous phase was collected and absorbance was checked at $600 \mathrm{~nm}$. The optical density readings were used to calculate the percentage of cell surface hydrophobicity of isolate adhering to solvent [23]. 


\subsubsection{Growth at Different $\mathrm{pH}$ Values and Bile Concentrations}

Isolates were grown in MRS broth adjusted to $\mathrm{pH}$ 2, 2.5, 3.5, 7.5 and 8.5 for $24 \mathrm{~h}$ at $37^{\circ} \mathrm{C}$. The assay was conducted in sterile flat-bottom 96-well microtitre plates. Each well was filled with $180 \mu \mathrm{l}$ of the medium and inoculated with $20 \mu \mathrm{l}$ of the overnight cultures obtained in MRS broth (O.D. at $600 \mathrm{~nm}$ is 0.2 ) at $37^{\circ} \mathrm{C}$. Optical density readings were recorded at $600 \mathrm{~nm}$ every hour for $8 \mathrm{~h}$ and after $24 \mathrm{~h}$, while cultures grown in MRS broth pH 6.5 served as the control [24]. The experiment was performed in triplicates. Similarly, isolates were grown in MRS broth containing $0.05 \%, 0.1 \%, 0.3 \%$ and $0.6 \%$ of oxgall for $24 \mathrm{~h}$. Optical density readings were recorded at $600 \mathrm{~nm}$ every hour for $8 \mathrm{~h}$ and after $24 \mathrm{~h}$. Isolates grown in MRS broth without oxgall served as control.

\subsection{3. $\beta$-Galactosidase Activity}

Isolates were grown in MRS-lac broth and cells were harvested by centrifugation at $8000 \mathrm{rpm}$ for $10 \mathrm{~min}$. The cells were washed with saline and suspended in the $\mathrm{Z}$ buffer $\left(60 \mathrm{mM} \mathrm{Na} \mathrm{HPO}_{4}, 40 \mathrm{mM} \mathrm{NaH} \mathrm{PO}_{4}, 50 \mathrm{mM}\right.$ $\beta$-mercaptoethanol pH7.0) and processed as described by Vinderola and Reinheimer, 2003 [25]. The suspended cells were permeabilized with toluene/acetone $(1: 9, \mathrm{v} / \mathrm{v})$. The reaction mixture having $900 \mu \mathrm{l}$ of Z buffer, $100 \mu \mathrm{l}$ of permeabilized cells and $200 \mu \mathrm{l}$ of ONPG $(4 \mathrm{mg} / \mathrm{mL})$ was incubated at $37^{\circ} \mathrm{C}$ for $15 \mathrm{~min}$. The reaction was stopped with the addition of $1 \%$ sodium carbonate and absorbance was measured at $550 \mathrm{~nm}$ and $420 \mathrm{~nm}$. The enzymatic activity was measured in Miller units.

$$
\beta \text {-galactosidase activity }(\mathrm{MU})=1000 \times \frac{A_{420}-1.75 \times A_{560}}{\text { Time of incubation } \times \text { Volume of culture } \times A_{550}}
$$

\subsubsection{Hemolytic and Bile Salt Hydrolase Activity}

For testing hemolytic activity, isolates were streaked on Columbia agar plates (Himedia, India), containing 5\% $(\mathrm{w} / \mathrm{v})$ human blood, and incubated for $24 \mathrm{~h}$ at $37^{\circ} \mathrm{C}$. Blood agar plates were checked for signs of $\beta$-hemolysis (clear zones around the colonies), $\alpha$-hemolysis (green-hued zones around the colonies) or $\gamma$-hemolysis (no zones around the colonies) [26]. Escherichia coli MTCC 728 and Streptococcus pyogenes MTCC 442 were used as control for $\alpha$ - and $\beta$-hemolysis, respectively.

Bile salt hydrolase (BSH) activity was assayed according to Lee et al., 2011 [27]. Isolates were streaked on MRS agar plates supplemented with $0.5 \%$ (w/v) sodium salt of taurodeoxycholic acid and $0.37 \mathrm{~g} \mathrm{CaCl}_{2} / \mathrm{L}$. The BSH activity was semi-quantified by the precipitation zones around the colonies after incubating anaerobically at $37^{\circ} \mathrm{C}$ for $24 \mathrm{~h}$.

\section{Results and Discussion}

\subsection{Isolation and Screening of Lactobacillus for Antibacterial and Antifungal Activity}

Lactic acid bacteria were isolated from GIT of seven weeks old broiler chicken. A total of 113 Lactobacillus strains (47 from crop, 8 from gizzard, 27 from intestine and 31 from ceca) were isolated based on their ability to grow on acidified MRS agar medium. All 113 isolates were screened for antibacterial activity against various LAB and food borne pathogens. All isolates showed activity against tested LAB and bacterial pathogens. Approximately 53\% (60 isolates) of the total isolates showed good antibacterial activity against bacterial pathogens L. monocytogenes, S. aureus and E. coli, indicating that Lactobacillus isolates from chicken origin are potential candidates for producing antibacterial metabolites. These isolates were further screened for antifungal activity against filamentous fungi Aspergillus niger and Penicillium expansum. Among the tested spoilage fungi, Aspergillus niger growth was inhibited by a dominant number of isolates, whereas Penicillium expansum growth was affected by few isolates. A total of six bacilli isolates VJC6, VJC11, VJC13, VJC23, VJI16 and VJI17 having similar morphology (Figure 1) were chosen for further study, based on their capability to inhibit all tested bacterial pathogens and food spoilage fungi (Figure 2 \& Figure 3, Table $1 \&$ Table 2). All the six isolates were found to be bacteriocinogenic in nature as they lost antibacterial activity upon treatment with acid protease [14] [28] (Figure 2(a), while the antifungal activity persisted indicating a non-proteinaceous substance was involved (Figure 3(b)). In the earlier study by Y.I Hassan and L.B. Bullerman, 2008 [12], it was reported that Aspergillus species were the most resistant to antifungal activity and difficult to inhibit by LAB. In our study, all the six isolates showed complete inhibition of Aspergillus niger for 7 days and continued to show same even for 3 months, indicated their preserving ability against fungal spoilage (Figure S1). These isolates were identified by 16S rRNA 


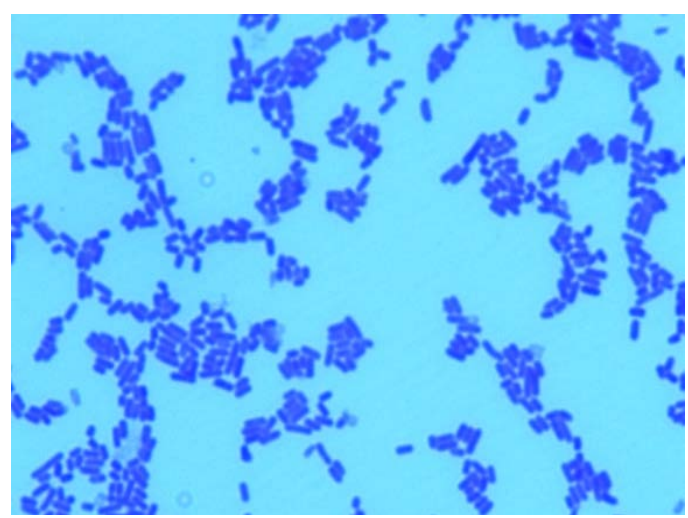

Figure 1. Morphology of one of the bacilli isolates (Gram's staining) from chicken gastro intestinal tract.

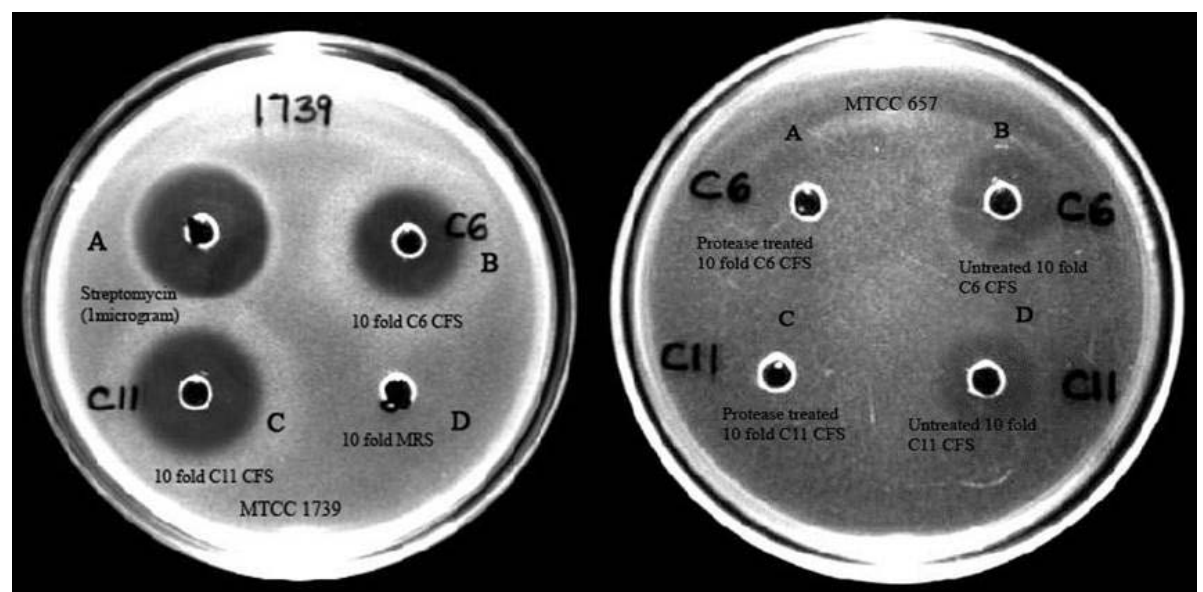

(a)

(b)

Figure 2. (a) Inhibitory activity against Staphylococcus aureus. (A) Streptomycin (1 $\mu \mathrm{g})$, (B) 10-fold-concentrate of cell free supernatant of VJC6, (C) 10-fold-concentrate of cell free supernatant of VJC13, (D)10-fold-concentrate of MRS broth; (b) Effect of acid Protease on antilisterial activity of 10-fold-concentrated CFS. (A) and (C) are Protease treated 10-fold cell free supernatant of VJC6 and VJC11 respectively whereas (B) and (D) are protease untreated.

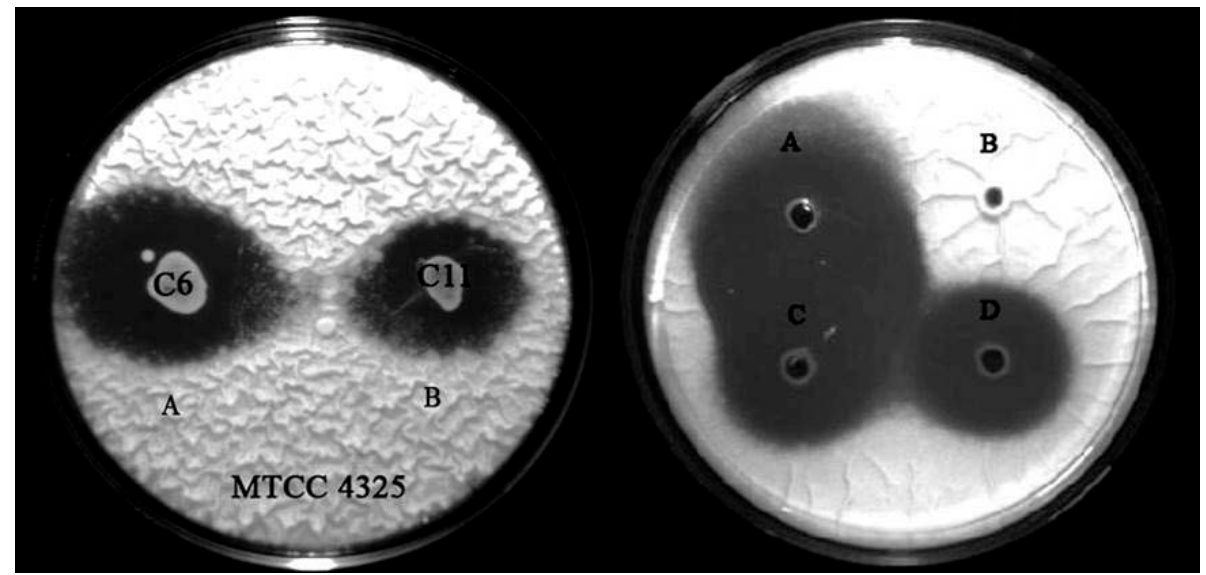

(a)

(b)

Figure 3. (a) Clear zones of inhibition of growth of Aspergillus niger formed around (A) VJC6 and (B) VJC11on MRS agar; (b) Effect of acid protease on antifungal activity against A.niger of a 10-fold-concentrated culture filtrate of VJC6. (A) Sodium benzoate (10 mg), (B) 10-fold-concentrate of MRS broth treated with enzyme, (C) and (D) are Protease treated and untreated 10-fold-culture filtrate of VJC6 respectively. 
Table 1. Antimicrobial activity against LAB and various pathogens.

\begin{tabular}{cccccccc}
\hline Indicator strains & \multicolumn{7}{c}{ Inhibition zone in mm } \\
\cline { 2 - 7 } & VJC6 & VJC11 & VJC13 & VJC23 & VJI16 & VJI17 & Positive control \\
\hline Lactobacillus plantarum (MTCC 6161) & $10 \pm 0$ & $11 \pm 1$ & $10 \pm 0$ & $11 \pm 1$ & $10 \pm 0$ & $10 \pm 0$ & $25^{\mathrm{a}} \pm 2$ \\
Lactobacillus fermentum (MTCC 1745) & $12 \pm 1$ & $12 \pm 1$ & $11 \pm 1$ & $13 \pm 1$ & $12 \pm 11$ & $12 \pm 2$ & $26^{\mathrm{a}} \pm 1$ \\
Lactococcus lactis subsp. lactis (MTCC 440) & $12 \pm 2$ & $15 \pm 1$ & $12 \pm 1$ & $15 \pm 2$ & $13 \pm 1$ & $12 \pm 1$ & $27^{\mathrm{a}} \pm 2$ \\
Leuconostoc mesenteroides subsp. mesenteroides (MTCC 107) & $10 \pm 0$ & $11 \pm 1$ & $13 \pm 1$ & $12 \pm 1$ & $13 \pm 2$ & $12 \pm 1$ & $28^{\mathrm{a}} \pm 3$ \\
Lactococcus lactis subsp. chacetylactis (MTCC 3042) & $12 \pm 1$ & $13 \pm 1$ & $12 \pm 1$ & $14 \pm 2$ & $12 \pm 1$ & $11 \pm 1$ & $28^{\mathrm{a}} \pm 2$ \\
Lactobacillus rhamnosus (MTCC 1408) & $11 \pm 1$ & $11 \pm 0$ & $10 \pm 0$ & $10 \pm 0$ & $10 \pm 0$ & $10 \pm 0$ & $26^{\mathrm{a}} \pm 2$ \\
Pseudomonas aeruginosa (MTCC 2295) & $19 \pm 1$ & $21 \pm 1$ & $20 \pm 2$ & $19 \pm 1$ & $20 \pm 2$ & $20 \pm 1$ & $21^{\mathrm{b}} \pm 1$ \\
Listeria monocytogenes (MTCC 657) & $18 \pm 1$ & $21 \pm 2$ & $16 \pm 1$ & $20 \pm 2$ & $16 \pm 1$ & $17 \pm 2$ & $28^{\mathrm{a}} \pm 3$ \\
Staphylococcus aureus subsp. aureus (MTCC 737) & $21 \pm 1$ & $23 \pm 2$ & $21 \pm 1$ & $20 \pm 0$ & $19 \pm 1$ & $22 \pm 1$ & $26^{\mathrm{a}} \pm 1$ \\
Escherichia coli (MTCC 728) & $20 \pm 1$ & $23 \pm 1$ & $19 \pm 1$ & $20 \pm 0$ & $18 \pm 1$ & $19 \pm 2$ & $32^{\mathrm{b}} \pm 1$ \\
Aeromonas hydrophila subsp. hydrophila (MTCC 1739) & $18 \pm 1$ & $20 \pm 0$ & $17 \pm 1$ & $20 \pm 2$ & $17 \pm 1$ & $16 \pm 1$ & $23^{\mathrm{b}} \pm 2$ \\
\hline
\end{tabular}

${ }^{\mathrm{a}}$ Ampicillin $(5 \mu \mathrm{g})$, ${ }^{\mathrm{b}}$ Streptomycin $(2.5 \mu \mathrm{g})$. Mean ( \pm standard deviation) of results of three experiments.

Table 2. Antifungal inhibition spectrum of Lactobacillus isolates in agar over layer method.

\begin{tabular}{|c|c|c|c|c|c|c|}
\hline \multirow{2}{*}{ Indicator organisms } & \multicolumn{6}{|c|}{ Antifungal performance of isolates } \\
\hline & VJC6 & VJC11 & VJC13 & VJC23 & VJI16 & VJI17 \\
\hline \multicolumn{7}{|l|}{$\underline{\text { Molds }}$} \\
\hline Aspergillus niger MTCC 4325 & ++ & ++ & +++ & ++ & +++ & ++ \\
\hline Aspergillus flavus MTCC & ++ & ++ & ++ & ++ & ++ & ++ \\
\hline Penicillium expansum MTCC 8241 & ++ & ++ & ++ & + & ++ & ++ \\
\hline Penicillium roqueforti MTCC 933 & + & + & + & + & + & + \\
\hline Eurotium species MTCC 4647 & ++ & + & ++ & + & +++ & + \\
\hline \multicolumn{7}{|l|}{$\underline{\text { Yeasts }}$} \\
\hline Candida albicans MTCC & ++ & + & ++ & + & ++ & + \\
\hline Endomyces fibuliger MTCC 1027 & + & - & + & + & ++ & - \\
\hline
\end{tabular}

The following scale was used: $(-)$ no visible inhibition; $(+)$ spore formation delayed with a small clear zone around the colony; $(++)$ spore formation delayed with a good clear zone around the colony; $(+++)$ extensive suppression of spore formation and mycelial growth with definite clear zone around the colony.

gene sequence and multiplex PCR analysis. The genomic variability of six isolates was studied by RAPD PCR analysis.

\subsection{Biochemical and Physiological Characterization}

All the isolates were Gram-positive, catalase-negative, rod shaped, aerobic or micro-aerobic, homo fermentative bacteria, and produce D and L-lactic acid (10 - $20 \mathrm{mM})$. These morphological characters suggested that all the isolates belonged to the genus Lactobacillus [29]. All the Lactobacillus strains grew in wide ranges of $\mathrm{NaCl}$ concentrations $(1 \%-6.5 \%)$, temperatures $\left(15^{\circ} \mathrm{C}-37^{\circ} \mathrm{C}\right)$ and $\mathrm{pH}(4.5-8.5)$, with optimum growth at $\mathrm{pH} 6.5$. The biochemical tests revealed that all Lactobacillus strains were acetoin producers and unable to hydrolyze gelatin, starch and arginine. The carbon utilization pattern was checked for six Lactobacillus strains and they can ferment glucose, fructose, sucrose, mannose, lactose and trehalose, but not xylose, raffinose, glycerol, melibiose, sodium gluconate, erythritol, $\alpha$-methyl-D-glucoside and $\alpha$-methyl-D-mannoside. The sugar profiles of the six isolates were varied and broad (Table S1). Biochemical studies indicated that all the six isolates belonged to Lactobacillus genus.

\subsection{Antibiotic Susceptibility}

All the six isolates were assayed for their susceptibility to 22 antibiotics (Table S2). They were found resistant 
to inhibitors of nucleic acid synthesis (norfloxacin, nalidixic acid and ciprofloxacin), inhibitors of protein synthesis (amikacin and streptomycin), inhibitors of cell wall synthesis (cepharadine and cephaloridine), an inhibitor of cytoplasmic membrane function (colistin), urinary tract antiseptic (nitrofurantoin) and sensitive to chloramphenicol, tetracycline, erythromycin, lincomycin, mecillinam, ampicillin, penicillin-G, and co-trimoxazole. The observed antibiotic resistance and sensitivity are in accordance with the findings of Mathur and Singh, 1995 [30].

\subsection{Genotypic Characterization by RAPD-PCR}

To exclude the clonal relatedness among the six isolates, RAPD analysis was performed using two primers M13 and R2. The reproducibility of the RAPD analysis was assessed by comparing the PCR products obtained from two separate cultures of the same strain for all the six isolates. Among two primers, M13 was the most useful for distinguishing six Lactobacillus strains, producing a variant DNA banding pattern for all the six isolates (Figure S2). The UPGMA dendrogram analysis revealed that the six Lactobacillus strains were genetically different at strain level and there was a more genetic distance at the strain level between VJI17, VJC23 and the rest of the isolates (Figure S3).

\subsection{Comparative 16S rRNA Sequence Analysis and Multiplex PCR Assay}

The 16S rRNA gene of the six isolates was sequenced and analysed for similarities using NCBI BLAST search program. It showed that all the six isolates had high sequence similarity (100\%) to Lactobacillus plantarum (AF1), Lactobacillus paraplantarum (N957) and Lactobacillus pentosus (MH53). As these three species are genotypically closely related ( $>97 \%), 16$ S ribosomal DNA sequences of the isolates are not suitable for species identification. The phylogenetic tree was constructed using the neighbor-joining method (Figure 4). The presumed six Lactobacillus strains were further confirmed at the species level by multiplex PCR. Multiplex PCR assay based on recA gene gave the amplification product of $318 \mathrm{bp}$ for all the six isolates belonging to Lactobacillus plantarum (Figure S4). The 16S rRNA analysis and multiplex PCR assay conferred that these isolates were belonged to Lactobacillus plantarum.

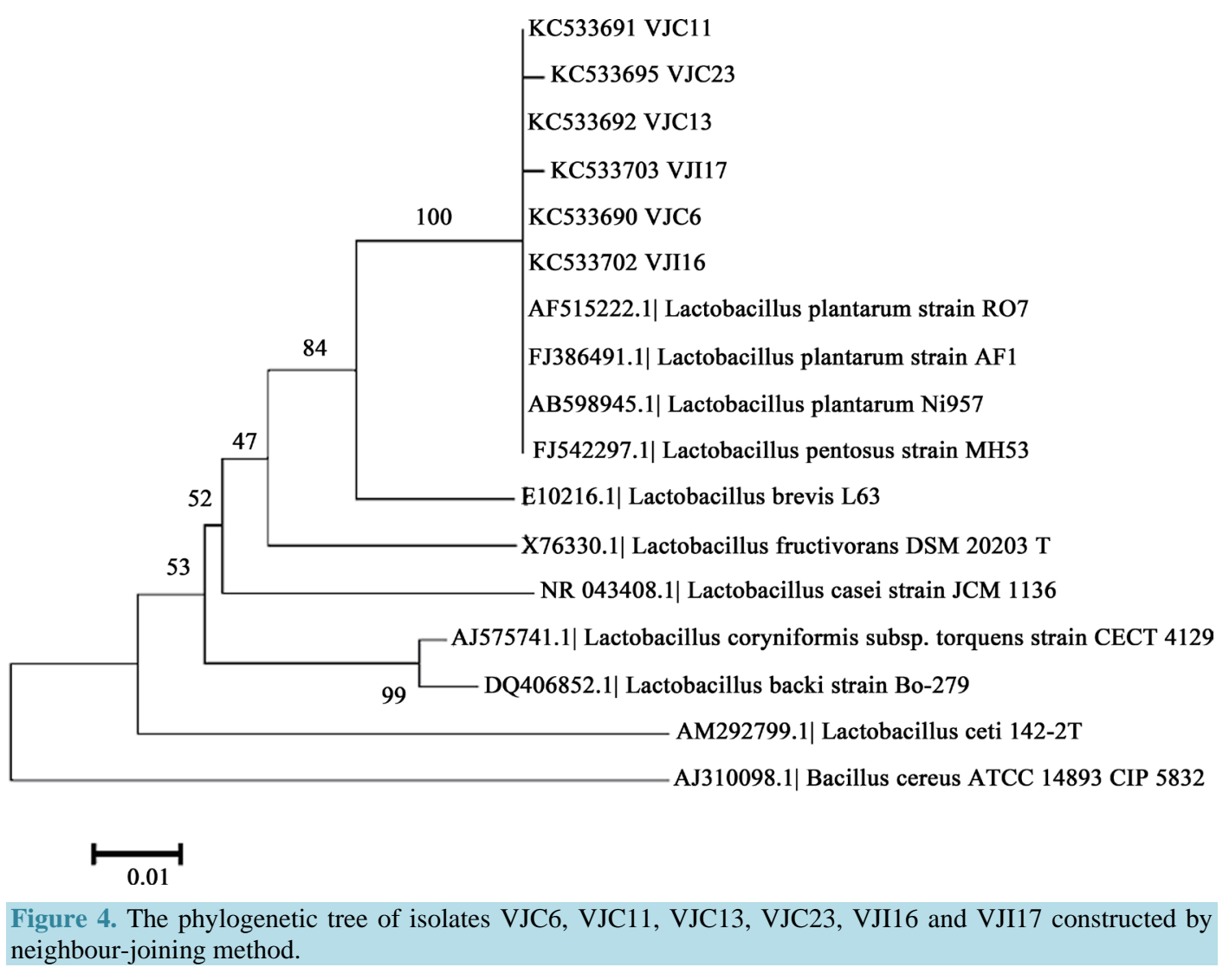




\subsection{Nucleotide Sequence Accession Numbers}

The 16S rRNA sequences of L. plantarum were deposited in the Gen Bank sequence database under accession numbers KC533690 (VJC6), KC533691 (VJC11), KC533692 (VJC13), KC533695 (VJC23), KC533702 (VJI16) and KC533703 (VJI17).

\subsection{PCR Amplification and Cloning of Plantaricin EF Gene}

The isolates were tested for the presence of known bacteriocin genes by PCR. Plantaricin EF specific primers plnEF-F and plnEF-R were used to amplify and sequence a 306 bp fragment from all the isolates (Figure S5). The nucleotide sequence showed 99\% similarity to the plantaricin E and F genes on the genome of Lactobacillus plantarum strain C11 (Gen Bank: X94434.2). The sequence analysis by BLAST at NCBI with published sequences revealed that PCR amplified $306 \mathrm{bp}$ fragment consisting of a partial plnE gene (1 - $108 \mathrm{bp}$ ) and a complete plnF gene (133 - 291) (Gen Bank: KM347970). The plnEF gene was cloned in to pTZ57R/T cloning vector by TA cloning method and transformed in to E. coli DH5 $\alpha$ cells. Double digestion of the recombinant vector with EcoR I and Hind III enzymes, resulted in the release of 400 bp insert and vector fragment (Figure S6). Plantaricin is a type IIb two-peptide bacteriocin obtained from different strains of Lactobacillus plantarum [31].

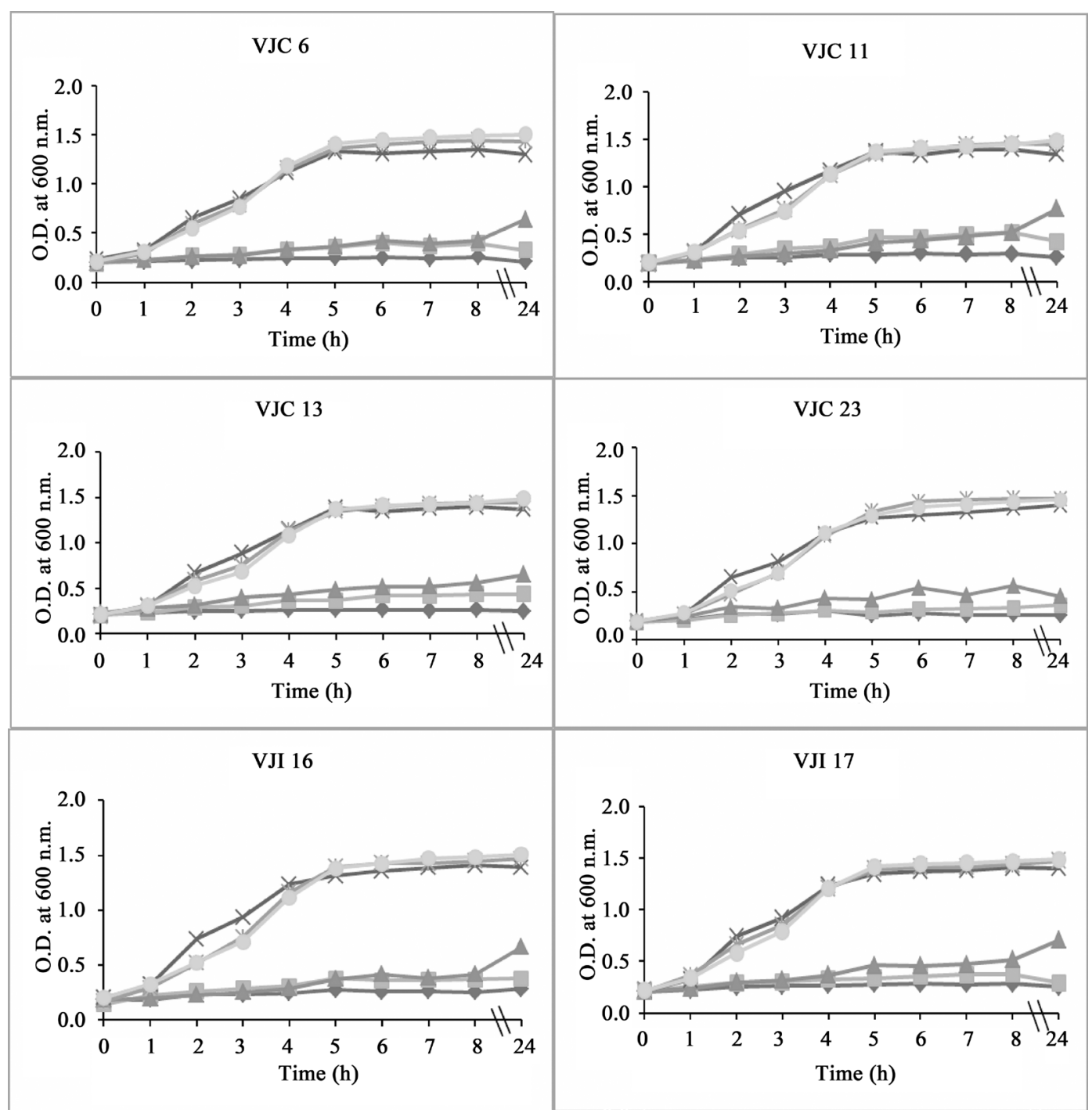

Figure 5. Comparison of growth of isolates VJC6 (A), VJC11 (B), VJC13(C), VJC23 (D), VJI16 (E) and VJI17 (F) in MRS broth at different $\mathrm{pH}$ levels. $\rightarrow 2 \div-2.5 \div 3.5 \div 6.5 \div 7.5 \rightarrow-8.5$ 
These findings further confirmed that the isolates were belonged to Lactobacillus plantarum and bacteriocinogenic nature may be due to the expression of plnE and F genes.

\subsection{Probiotic Properties of Lactobacillus}

Autoaggregation and coaggregation are vital properties of a probiotic organism, responsible for biofilm formation on the gut epithelium. The binding of probiotic organism with intestinal pathogens will be helpful to kill pathogens by antimicrobial substances [32]. All the isolates exhibited bacteriocinogenic mode antibacterial activity. The tested isolates exhibited strong autoaggregating phenotype ranged from $78 \%-86 \%$, which assist in binding firmly with intestinal epithelium. The Lactobacillus strains showed the most coaggregation ability with E.coli MTCC 728 (49\% - 61\%) when compared to L. monocytogenes MTCC 657 (30\% - 46\%). The resistance to harsh conditions of the stomach and intestine is another essential prerequisite for probiotic organism. The physiological $\mathrm{pH}$ of the stomach is $2-3$ and bile concentration is $0.3 \%$ [33]. A good probiotic must be resistant to the acidic nature of the stomach and the physiological bile concentration. The isolates were remained unaffected by the acidic $\mathrm{pH} 2.0$ - 3.5 and good growth was observed at pH 6.5 - 8.5 (Figure 5). They also showed resistance and growth in the presence of $0.6 \%$ of bile, indicating that these isolates can survive even at high

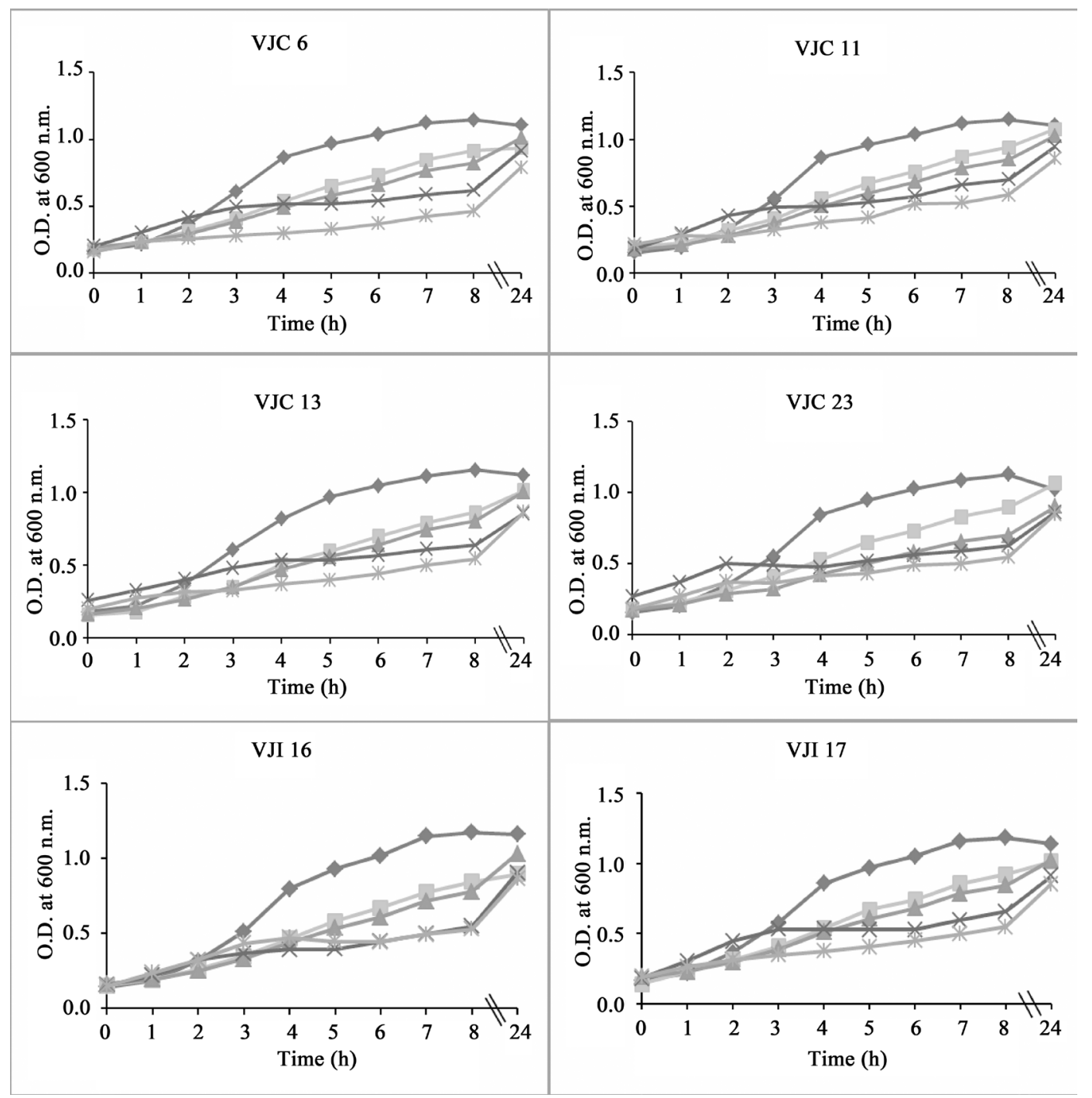

Figure 6. Comparison of growth of VJC6 (A), VJC11 (B), VJC13 (C), VJC23 (D), VJI16 (E) and VJI17 (F) in MRSbroth at different bile concentrations. $\rightarrow-0.00 \%+0.05 \%+0.10 \% \div 0.30 \% \div 0.60 \%$ 
Table 3. Probiotic properties of isolates.

\begin{tabular}{|c|c|c|c|c|c|c|}
\hline Properties & VJC6 & VJC11 & VJC13 & VJC23 & VJI16 & VJI17 \\
\hline Autoaggregation (\%) & $86.21 \pm 0.50$ & $86.28 \pm 0.48$ & $85.36 \pm 1.08$ & $86.50 \pm 0.64$ & $86.92 \pm 0.88$ & $78.97 \pm 0.86$ \\
\hline Coaggregation with L.monocytogenes (\%) & $38.78 \pm 0.40$ & $30.00 \pm 0.70$ & $41.27 \pm 0.50$ & $36.02 \pm 0.40$ & $34.50 \pm 0.27$ & $45.83 \pm 0.50$ \\
\hline Coaggregation with Escherichia coli (\%) & $56.57 \pm 0.40$ & $55.52 \pm 0.35$ & $61.49 \pm 1.50$ & $49.38 \pm 0.50$ & $49.38 \pm 0.50$ & $51.77 \pm 1.17$ \\
\hline Cell-surface hydrophobicity (\%) & $29.80 \pm 0.23$ & $33.29 \pm 0.84$ & $16.35 \pm 0.32$ & $45.16 \pm 0.25$ & $29.41 \pm 0.12$ & $28.70 \pm 0.24$ \\
\hline$\beta$-galactosidase activity (MU) & $1074 \pm 7$ & $1059 \pm 10$ & $1179 \pm 5$ & $1166 \pm 11$ & $1036 \pm 5$ & $1106 \pm 6$ \\
\hline Bile salt hydrolase activity & + & + & + & + & + & + \\
\hline Hemolytic activity & - & - & - & - & - & - \\
\hline
\end{tabular}

Mean ( \pm standard deviation) of results of three experiments, + : positive; - : negative.

concentrations of bile (Figure 6). Bacterial cell hydrophobicity may assist in adhesion, but does not seem to be a prerequisite for colonization [34]. The $L$. plantarum strains showed hydrophobicity ranging from $16 \%-33 \%$ with n-hexadecane. Lactose intolerance is caused by deficiency $\beta$-galactosidase in the lining of duodenum. So, the food products, fermented with lactase producers could help to treat lactose intolerance. All the isolates showed $\beta$-galactosidase activity. Among the isolates, VJC13 showed maximum $\beta$-galactosidase activity (1179 MU) may have application in the dairy industry. In this study no isolate showed hemolytic activity where as positive strains Escherichia coli MTCC 728 and Streptococcus pyogenes MTCC 442 showed $\alpha$ - and $\beta$-hemolysis, respectively. Table 3 gives the probiotic properties of the all the Lactobacillus strains.

\section{Conclusion}

In conclusion, chicken GIT is a good reservoir of potential antifungal, antibacterial and probiotic Lactobacillus plantarum strains with high diversity. The study of antifungal nature and probiotic properties in vivo of these isolates may lead to the development of lactic acid bacteria based preservative systems to prevent fungal spoilage in food and feed industries.

\section{Acknowledgements}

The authors acknowledge DST-FIST and UGC-SAP for financial assistance to the Department. Mr. Venkatasatyanarayana Nallala is thankful to Council of Scientific and Industrial Research (CSIR), New Delhi and University Grants Commission (UGC), New Delhi for the financial support in the form of fellowship.

\section{References}

[1] Legan, J.D. (1993) Mold Spoilage of Bread: The Problem and Some Solutions. International Biodeterioration \& Biodegradation, 32, 33-53. http://dx.doi.org/10.1016/0964-8305(93)90038-4

[2] Nielsen, P.V. and de Boer, E. (2000) Food Preservatives against Fungi. In: Samson, R.A., Frisvad, J.C. and Filtenborg, O., Eds., Introduction to Food and Airborne Fungi, Centraal Bureau voor Schimmelcultures, Utrecht, 357-363.

[3] Prendergast, P. (1997) From Producerism to Consumerism-The Implications of Change. In: Sheridan, J.J., O’Keeffe, M. and Rogers, M., Food Safety: The Implications of Change from Producerism to Consumerism, the National Food Centre, Dublin, 15.

[4] Spicher, G. (1983) Baked Goods. In: Reed., G., Ed., Biotechnology, Vol. 5: Food and Feed Productions with Microorganisms, Verlag Chemie, Weinheim, Germany, 1-80.

[5] Udhyashree, N., Senbagam, D., Senthilkumar, B., Nithya, K. and Grusamy, R. (2012) Production of Bacteriocin and Their Application in Food Products. Asian Pacific Journal of Tropical Biomedicine, 2, S406-S410. http://dx.doi.org/10.1016/s2221-1691(12)60197-X

[6] Coloretti, F., Carri, S., Armaforte, E., Chiavari, C., Grazia, L. and Zambonelli, C. (2007) Antifungal Activity of Lactobacilli Isolated from Salami. FEMS Microbiology Letters, 271, 245-250. http://dx.doi.org/10.1111/j.1574-6968.2007.00723.x

[7] Schnürer, J. and Magnusson, J. (2005) Antifungal Lactic Acid Bacteria as Bio Preservatives. Trends in Food Science \& Technology, 16, 70-78. http://dx.doi.org/10.1016/j.tifs.2004.02.014

[8] Apajalahti, J., Kettunen, A. and Graham, H. (2004) Characterization of Gastrointestinal Microbial Communities, with 
Special Reference to the Chicken. World's Poultry Science Journal, 60, 223-232. http://dx.doi.org/10.1079/WPS20040017

[9] Lima, E.T., Andreatii Filho, R.L., Okamoto, A.S. and Crocci, A.J. (2007) Evaluation in Vitro of the Antagonistic Substances Produced by Lactobacillus spp. Isolated from Chickens. Canadian Journal of Veterinary Research, 71, 103107.

[10] Gong, J., Forster, R.J. and Yu, H. (2002) Molecular Analysis of Bacterial Populations in the Ileum of Broiler Chickens and Comparison with Bacteria in the Cecum. FEMS Microbiology Ecology, 41, 171-179. http://dx.doi.org/10.1111/j.1574-6941.2002.tb00978.x

[11] Reid, G., Sanders, M.E., Gaskins, H.R., Gibson, G.R., Mercenier, A., Rastall, R., Roberfroid, M., Rowland, I., Cherbut, C. and Klaenhammer, T.R. (2003) New Scientific Paradigms for Probiotics and Prebiotics. Journal of Clinical Gastroenterology, 37, 105-118. http://dx.doi.org/10.1097/00004836-200308000-00004

[12] Hassan, Y.I. and Bullerman L.B. (2008) Antifungal Activity of Lactobacillus paracasei ssp. Tolerans Isolated from a Sourdough Bread Culture. International Journal of Food Microbiology, 121, 112-115. http://dx.doi.org/10.1016/j.ijfoodmicro.2007.11.038

[13] Agaliya, P. and Jeevaratnam, K. (2013) Molecular Characterization of Lactobacilli Isolated from Idli Batter. Brazilian Journal of Microbiology, 44, 1199-1206. http://dx.doi.org/10.1590/s1517-83822013000400025

[14] Moraes, P.M., Perin, L.M., Ortolani, M.B.T., Yamazi, A.K., Vicosa, G.N. and Nero, L.A. (2010) Protocols for the Isolation and Detection of Lactic Acid Bacteria with Bacteriocinogenic Potential. LWT-Food Science and Technology, 43, 531-541.

[15] Jamuna, M. and Jeevaratnam, K. (2004) Isolation and Characterization of Lactobacilli from Some Traditional Fermented Foods and Evaluation of the Bacteriocins. Journal of General and Applied Microbiology. 50, 70-90. http://dx.doi.org/10.2323/igam.50.79

[16] Saraniya, A. and Jeevaratnam, K. (2012) Molecular Characterization of Bacteriocinogenic Lactobacillus Species from Fermented Uttapam Batter. Biosciences Biotechnology Research Asia, 9, 417-421. http://dx.doi.org/10.13005/bbra/1017

[17] Vidhyasagar, V. and Jeevaratnam, K. (2012) Isolation and Characterization of Pediococcus pentosaceus from Idli Batter: A Traditional South Indian Fermented Food Source. Biosciences Biotechnology Research Asia, 9, 427-431. http://dx.doi.org/10.13005/bbra/1019

[18] CLSI (2011) Performance Standards for Antimicrobial Susceptibility Testing; Twenty-First Informational Supplement. Clinical and Laboratory Standards Institute, Pennsylvania.

[19] Anderson, D.G. and McKay, L.L. (1983) Simple and Rapid Method for Isolating Large Plasmid DNA from Lactic Streptococci. Applied and Environmental Microbiology, 46, 549-552.

[20] Torriani, S., Felis, G. and Dellaglio, F. (2001) Differentiation of Lactobacillus plantarum, L. pentosus and L. paraplantarum, by recA Gene Sequence Analysis and Multiplex PCR Assay with recA Gene-Derived Primers. Applied and Environmental Microbiology, 67, 3450-3454. http://dx.doi.org/10.1128/AEM.67.8.3450-3454.2001

[21] Diep, D.B., Håvarstein, L.S. and Nes, I.F. (1996) Characterization of the Locus Responsible for the Bacteriocin Production in Lactobacillus plantarum C11. Journal of Bacteriology, 178, 4472-4483.

[22] Sambrook, J., Maccallum, P. and Russell, D. (2001) Molecular Cloning: A Laboratory Manual. 3rd Edition, Cold Spring Harbor Press, New York, 2344.

[23] Osmanagaoglu, O., Kiran, F. and Ataoglu, H. (2010) Evaluation of in Vitro Probiotic Potential of Pediococcus pentosaceus OZF Isolated from Human Breast Milk. Probiotics and Antimicrobial Proteins, 2, 162-174. http://dx.doi.org/10.1007/s12602-010-9050-7

[24] Todorov, S.D., Furtado, D.N., Saad, S.M.I., Tome, E. and Franco, B.D.G.M. (2011) Potential Beneficial Properties of Bacteriocin Producing Lactic Acid Bacteria Isolated from Smoked Salmon. Journal of Applied Microbiology, 110, 971-986. http://dx.doi.org/10.1111/j.1365-2672.2011.04950.x

[25] Vinderola, C.G. and Reinheimer, J.A. (2003) Lactic Acid Starter and Probiotic Bacteria: A Comparative "in Vitro" Study of Probiotic Characteristics and Biological Barrier Resistance. Food Research International, 36, 895-904. http://dx.doi.org/10.1016/s0963-9969(03)00098-X

[26] Maragkoudakis, P.A., Zoumpopoulou, G., Miaris, C., Kalantzopoulos, G., Pot, B. and Tsakalidou, E. (2006) Probiotic Potential of Lactobacillus Strains Isolated from Dairy Products. International Dairy Journal, 16, 189-199. http://dx.doi.org/10.1016/j.idairyj.2005.02.009

[27] Lee, H., Yoon, H., Ji, Y., Kim, H., Park, H., Lee, J., Shin, H. and Holzapfel, W. (2011) Functional Properties of Lactobacillus Strains Isolated from Kimchi. International Journal of Food Microbiology, 145, 155-161. http://dx.doi.org/10.1016/j.ijfoodmicro.2010.12.003

[28] Vijayendra, S.V.N., Rajashree, K. and Halami, P.M. (2010) Characterization of Heat Stable Anti-Listerial Bacteriocin 
Produced by Vancomycin Sensitive Enterococcus faecium Isolated From Idli Batter. Indian Journal of Microbiology, 50, 243-246. http://dx.doi.org/10.1007/s12088-010-0030-0

[29] Pal, V., Jamuna, M. and Jeevaratnam, K. (2005) Isolation and Characterization of Bacteriocin Producing Lactic Acid Bacteria from a South Indian Special Dosa (appam) Batter. Journal of Culture Collections, 4, 53-60.

[30] Mathur, S. and Singh, R. (2005) Antibiotic Resistance in Food Lactic Acid Bacteria-A Review. International Journal of Food Microbiology, 105, 281-295. http://dx.doi.org/10.1016/j.ijfoodmicro.2005.03.008

[31] Hauge, H.H., Mantzilas, D., Eijsink, V.G.H. and Nissen-meyer, J. (1999) Membrane Mimicking Entities Induce Structuring of the Two-Peptide Bacteriocins Plantaricin E/F and Plantaricin J/K. Journal of Bacteriology, 181, 740-747.

[32] Reid, G., McGroarty, J.A., Angotti, R. and Cook, R.L. (1988) Lactobacillus Inhibitor against Escherichia coli and Coaggregation Ability with Uropathogens. Canadian Journal of Microbiology, 34, 344-351. http://dx.doi.org/10.1139/m88-063

[33] Goldin, B.R., Gorbach, S.L., Saxelin, M., Barakat, S., Gualtieri, L. and Salminen, S. (1992) Survival of Lactobacillus Species (Strain GG) in Human Gastrointestinal Tract. Digestive Diseases and Sciences, 37, 121-128. http://dx.doi.org/10.1007/BF01308354

[34] Todorov, S.D. and Dicks, L.M.T. (2008) Evaluation of Lactic Acid Bacteria from Kefir, Molasses and Olive Brine as Possible Probiotics Based on Physiological Properties. Annals of Microbiology, 58, 661-670. http://dx.doi.org/10.1007/BF03175572 


\section{Supplementary Figures}

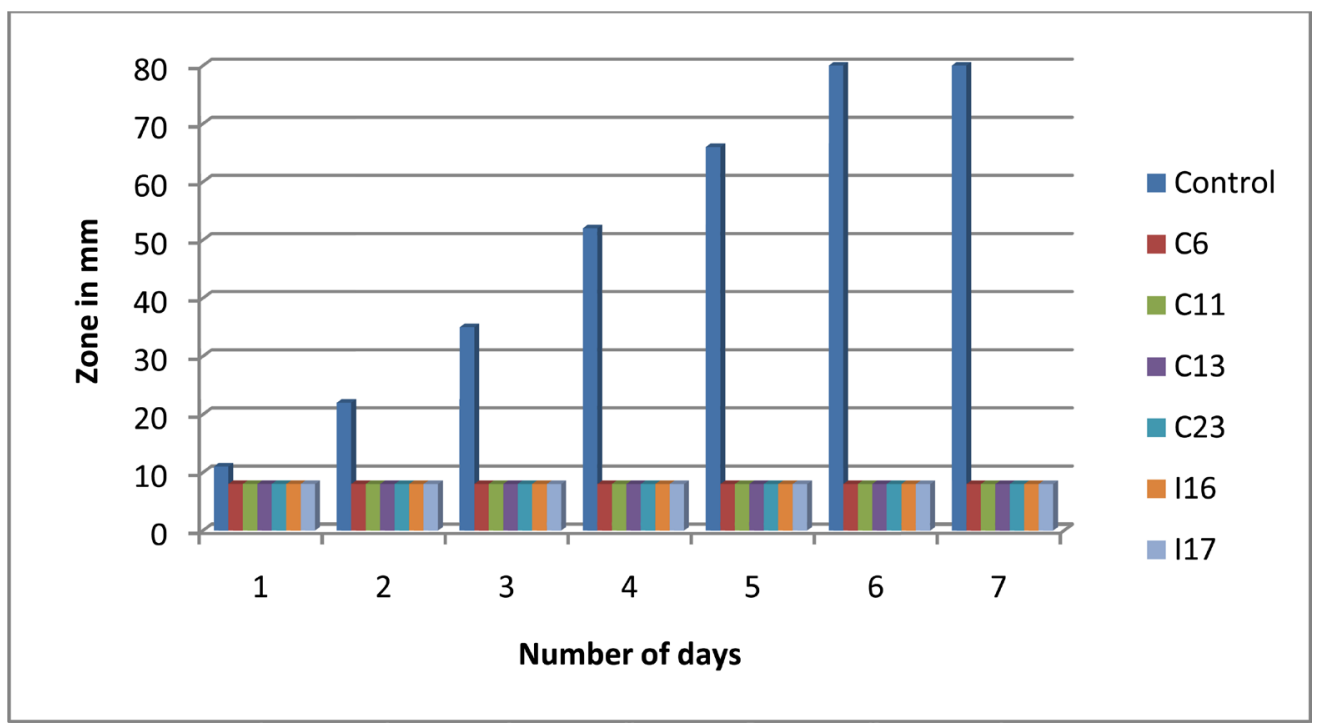

Figure S1. Inhibition of Aspergillus niger MTCC 4325 by Lactobacillus isolates in a dual agar layer system.

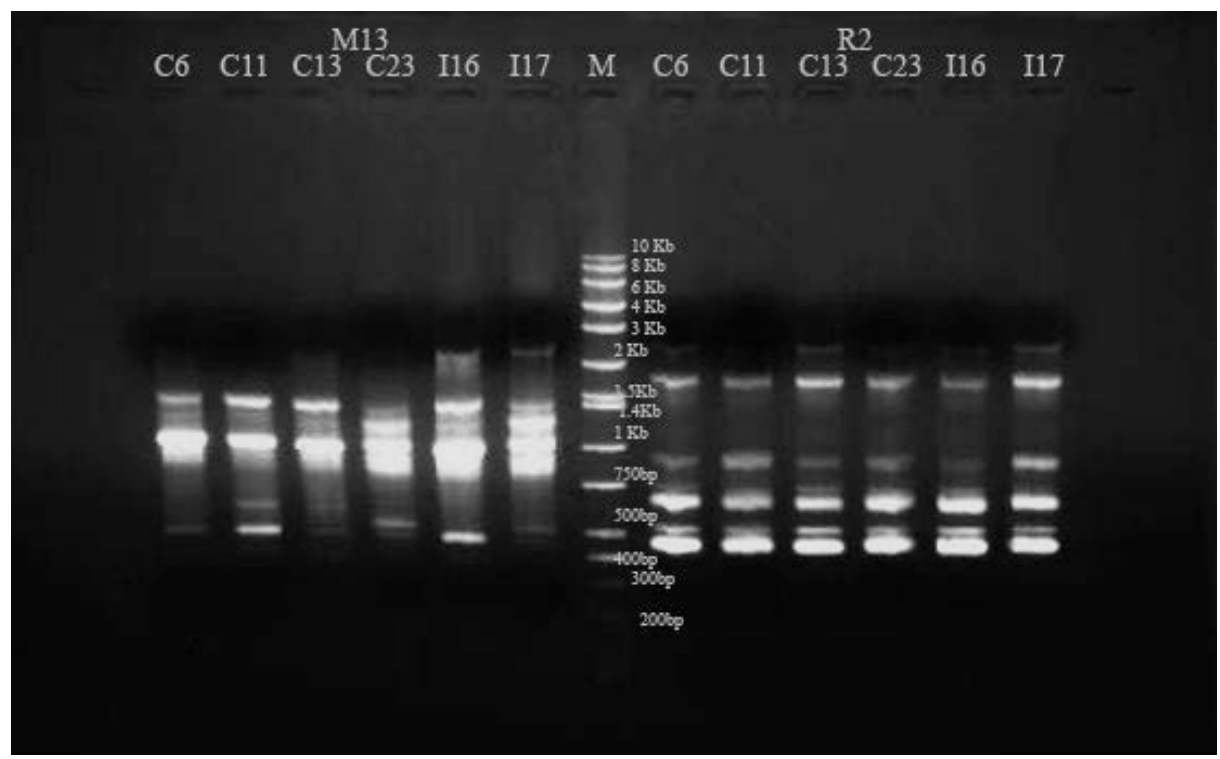

Figure S2. M13 and R2 RAPD analysis of six potent strains.

0.39

0.60

0.80 1.00

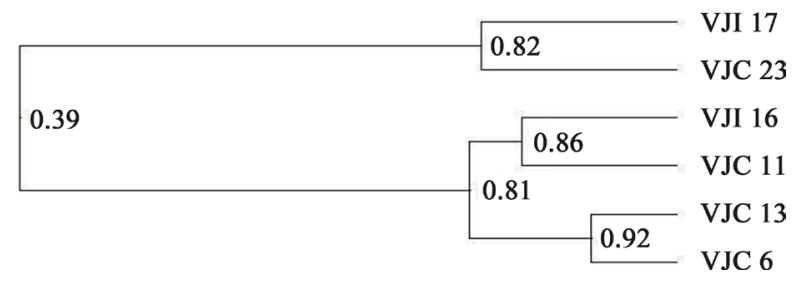

Figure S3. Dendrogram based on the UPGMA clustering analysis and the Dice coefficient of the M13 RAPD patterns. 


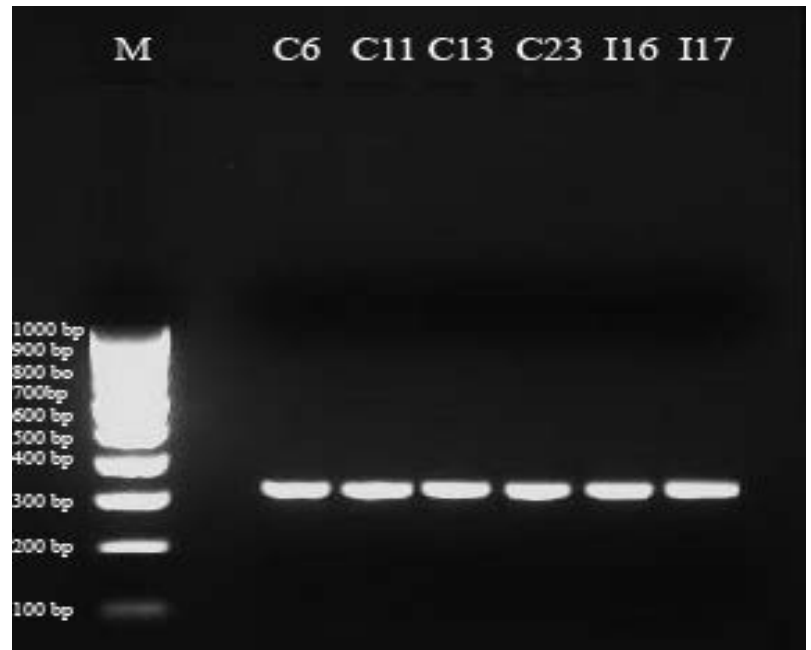

Figure S4. Multiplex PCR of six isolates.
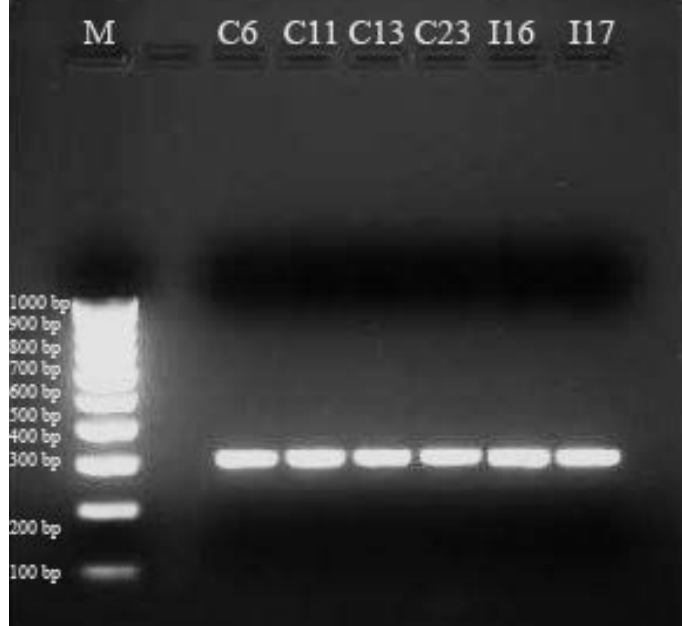

Figure S5. PCR amplification of plnEF gene of six potent strains.

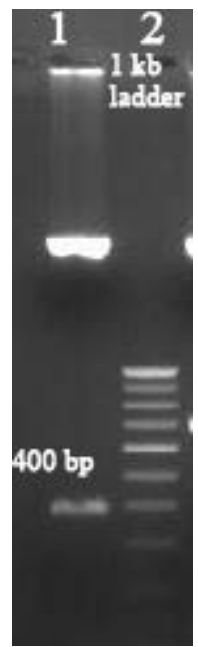

Figure S6. EcoR I and Hind III digestion of recombinant vector pTZ57R/T with plnEF gene. 1) EcoR I and Hind III double digest product, 2) 1 kb DNA ladder. 


\section{Supplementary Tables}

Table S1. Biochemical characterization of the isolates.

\begin{tabular}{|c|c|c|c|c|c|c|}
\hline & VJC6 & VJC11 & VJC13 & VJC23 & VJI16 & VJI17 \\
\hline \multicolumn{7}{|l|}{ Carbohydrate Utilization } \\
\hline Lactose & + & + & + & + & + & + \\
\hline Xylose & - & - & - & - & - & - \\
\hline Maltose & - & + & + & + & + & + \\
\hline Fructose & + & + & + & + & + & + \\
\hline Dextrose & + & + & + & + & + & + \\
\hline Galactose & \pm & \pm & \pm & \pm & \pm & \pm \\
\hline Raffinose & - & - & - & - & - & - \\
\hline Trehalose & + & + & + & + & + & + \\
\hline Melibiose & - & - & - & - & - & - \\
\hline L-Arabinose & - & - & \pm & + & - & \pm \\
\hline D-Arabinose & \pm & - & - & \pm & - & - \\
\hline Mannose & + & + & + & + & + & + \\
\hline Inulin & + & + & + & + & + & \pm \\
\hline Sucrose & + & + & + & + & + & + \\
\hline Glycerol & - & - & - & - & - & - \\
\hline Sorbitol & \pm & - & - & - & - & - \\
\hline Mannitol & \pm & - & - & - & - & - \\
\hline Salicin & \pm & - & + & + & + & - \\
\hline Esculin hydrolysis & + & + & + & + & + & + \\
\hline Citrate utilization & - & - & - & - & - & - \\
\hline Sodium gluconate & - & - & - & - & - & - \\
\hline Cellobiose & + & + & + & + & + & \pm \\
\hline Erythritol & - & - & - & - & - & - \\
\hline Melezitose & + & + & + & + & + & \pm \\
\hline$\alpha$-methyl-D-mannoside & - & - & - & - & - & - \\
\hline$\alpha$-methyl-D-glucoside & - & - & - & - & - & - \\
\hline
\end{tabular}

Table S2. Antibiotic susceptibility profile of isolates from chicken GIT.

\begin{tabular}{|c|c|c|c|c|c|c|}
\hline Antibiotics & C6 & C11 & $\mathrm{C} 13$ & $\mathrm{C} 23$ & I16 & I17 \\
\hline \multicolumn{7}{|l|}{ Cell wall synthesis inhibitor } \\
\hline \multicolumn{7}{|l|}{ Penams } \\
\hline Ampicillin $(25 \mu \mathrm{g})$ & S & S & $\mathrm{S}$ & $\mathrm{S}$ & S & $\mathrm{S}$ \\
\hline Cloxacillin $(5 \mu \mathrm{g})$ & S & S & $\mathrm{S}$ & S & S & $\mathrm{S}$ \\
\hline Penicillin G (2 $\mu \mathrm{g})$ & $\mathrm{S}$ & S & $\mathrm{S}$ & $\mathrm{S}$ & S & $\mathrm{S}$ \\
\hline \multicolumn{7}{|l|}{ Cephams } \\
\hline 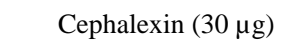 & $\mathrm{R}$ & $\mathrm{R}$ & $\mathrm{R}$ & $\mathrm{S}$ & $\mathrm{R}$ & $\mathrm{S}$ \\
\hline Cephaloridine (30 $\mu \mathrm{g})$ & $\mathrm{R}$ & $\mathrm{R}$ & $\mathrm{R}$ & $\mathrm{R}$ & $\mathrm{R}$ & $\mathrm{R}$ \\
\hline Cepharadine (30 $\mu \mathrm{g})$ & $\mathrm{R}$ & $\mathrm{R}$ & $\mathrm{R}$ & $\mathrm{R}$ & $\mathrm{R}$ & $\mathrm{R}$ \\
\hline Cefuroxime (30 $\mu \mathrm{g})$ & $\mathrm{R}$ & $\mathrm{S}$ & $\mathrm{R}$ & $\mathrm{S}$ & $\mathrm{S}$ & $\mathrm{S}$ \\
\hline Ceftriaxone $(30 \mu \mathrm{g})$ & $\mathrm{R}$ & S & $\mathrm{R}$ & $\mathrm{R}$ & $\mathrm{R}$ & $\mathrm{S}$ \\
\hline
\end{tabular}




\section{Continued}

\section{Others}

Mecillinam (33 $\mu \mathrm{g})$

Nucleic acid synthesis inhibitor

Norfloxacin $(300 \mu g)$

Ciprofloxacin $(10 \mu \mathrm{g})$

Nalidixic acid (30 $\mu \mathrm{g})$

Co-trimoxazole (25 $\mu g)$

$\underline{\text { Protein synthesis inhibitor }}$

Amikacin $(10 \mu \mathrm{g})$
Erythromycin $(10 \mu \mathrm{g})$
Gentamycin $(30 \mu \mathrm{g})$
Lincomycin $(10 \mu \mathrm{g})$
Streptomycin $(10 \mu \mathrm{g})$
Tetracyclin $(25 \mu \mathrm{g})$
Chloramphenicol $(25 \mu \mathrm{g})$
Urinary tract antiseptics
Nitrofurantoin $(300 \mu \mathrm{g})$

Cytoplasmic membrane function inhibitors

$\begin{array}{llllll}S & S & S & S & S & S\end{array}$

$\begin{array}{llllll}\mathrm{R} & \mathrm{R} & \mathrm{R} & \mathrm{R} & \mathrm{R} & \mathrm{R} \\ \mathrm{R} & \mathrm{R} & \mathrm{R} & \mathrm{R} & \mathrm{R} & \mathrm{R} \\ \mathrm{R} & \mathrm{R} & \mathrm{R} & \mathrm{R} & \mathrm{R} & \mathrm{R} \\ \mathrm{S} & \mathrm{S} & \mathrm{S} & \mathrm{S} & \mathrm{S} & \mathrm{S}\end{array}$

$\begin{array}{llllll}\mathrm{R} & \mathrm{R} & \mathrm{R} & \mathrm{R} & \mathrm{R} & \mathrm{R} \\ \mathrm{S} & \mathrm{S} & \mathrm{S} & \mathrm{S} & \mathrm{S} & \mathrm{S} \\ \mathrm{R} & \mathrm{S} & \mathrm{S} & \mathrm{R} & \mathrm{S} & \mathrm{S} \\ \mathrm{S} & \mathrm{S} & \mathrm{S} & \mathrm{S} & \mathrm{S} & \mathrm{S} \\ \mathrm{R} & \mathrm{R} & \mathrm{R} & \mathrm{R} & \mathrm{R} & \mathrm{R} \\ \mathrm{S} & \mathrm{S} & \mathrm{S} & \mathrm{S} & \mathrm{S} & \mathrm{S} \\ \mathrm{S} & \mathrm{S} & \mathrm{S} & \mathrm{S} & \mathrm{S} & \mathrm{S} \\ & & & & & \\ \mathrm{R} & \mathrm{R} & \mathrm{R} & \mathrm{R} & \mathrm{R} & \mathrm{R}\end{array}$

Colistin $(10 \mu \mathrm{g})$ 